$(0.70 \mathrm{mmol})$ of dibenzothiophene was added. After $48 \mathrm{~h}$ at $55^{\circ} \mathrm{C}$ the mixture was worked up, first with glacial acetic acid and then with $6 \mathrm{~N}$ aqueous $\mathrm{HCl}$. A sample of the biphenyl ( $95 \%$ ) was analyzed by MS and IR measurements. The product was a mixture of $14.3 \% 2,2^{\prime}$-dideuterioand $25.3 \%$ 2-deuteriobiphenyl, together with $60.4 \%$ biphenyl.

(e) Workup with o-Deuterioacetic Acid. The reaction between ( $\mathrm{CO}$ D) ${ }_{2} \mathrm{Ni}, 2,2^{\prime}$-bipyridyl, and $\mathrm{LiAlH}_{4}$ in $15 \mathrm{~mL}$ of THF was conducted on a $1.5 \mathrm{mM}$ scale as in section d. Workup with $\mathrm{CH}_{3} \mathrm{CO}_{2} \mathrm{D}$ gave $94.5 \%$ biphenyl and a mixture of $2.3 \%$ 2-deuterio- and $3.2 \%$ 2,2'-dideuteriobiphenyl.

Hydrodesulfurization of Dibenzothiophene (3) with Nickel Salts and Metal Hydrides. (a) 2,2'-Bipyridyl and $\mathrm{LiAlH}_{4}$. A solution of $200 \mathrm{mg}$ $(0.73 \mathrm{mmol})$ of nickel(II) acetylacetonate and $113 \mathrm{mg}(0.73 \mathrm{mmol})$ of $2,2^{\prime}$-bipyridyl in $15 \mathrm{~mL}$ of THF was treated with $26 \mathrm{mg}(0.73 \mathrm{mmol})$ of $\mathrm{LiAlH}_{4}$. After the brown solution was stirred for $30 \mathrm{~min}$ at $25^{\circ} \mathrm{C}, 67$ $\mathrm{mg}(0.36 \mathrm{mmol})$ of 3 was added. The reaction mixture was heated for $48 \mathrm{~h}$ at $55^{\circ} \mathrm{C}$ and then given the usual protolytic workup. A GLPC analysis showed a $36 \%$ conversion to biphenyl.

A reaction in which 6 molar equiv of $\mathrm{LiAlH}_{4}$ was used with 2 molar equiv each of $\mathrm{Ni}(\mathrm{acac})_{2}$ and $2,2^{\prime}$-bipyridyl to desulfurize 1 molar equiv dibenzothiophene gave $32 \%$ biphenyl.

(b) Use of $\mathrm{NaBH}_{4}$. A reaction analogous to that in section a, except that $\mathrm{NaBH}_{4}$ was substituted for $\mathrm{LiAlH}_{4}$, gave a $6 \%$ conversion to biphenyl, either in THF $\left(55^{\circ} \mathrm{C}\right)$ or in triglyme $\left(130^{\circ} \mathrm{C}\right)$.

(c) Use of Diisobutylaluminum Hydride. A green solution of $290 \mathrm{mg}$ $(1.83 \mathrm{mmol})$ of $\mathrm{Ni}(\mathrm{acac})$, and $285 \mathrm{mg}(1.83 \mathrm{mmol})$ of $2,2^{\prime}$-bipyridyl in $15 \mathrm{~mL}$ of toluene was stirred while being treated with $260 \mathrm{mg}(1.83$ $\mathrm{mmol})$ of $(i-\mathrm{Bu})_{2} \mathrm{AlH}$. Then $160 \mathrm{mg}(0.87 \mathrm{mmol})$ of 3 was added to the brown solution. After $24 \mathrm{~h}$ at reflux and the usual protolytic workup, a GLPC analysis showed a $38 \%$ conversion to biphenyl.

Hydrodesulfurization of 2,8-Dimethyldibenzothiophene (9). A deepviolet solution of 1 , prepared from $560 \mathrm{mg}(2.03 \mathrm{mmol})$ of $(\mathrm{COD}){ }_{2} \mathrm{Ni}$ and $220 \mathrm{mg}$ ( $2.03 \mathrm{mmol})$ of $2,2^{\prime}$-bipyridyl in $15 \mathrm{~mL}$ of THF, was treated first with $80 \mathrm{mg}(2.03 \mathrm{mmol})$ of $\mathrm{LiAlH}_{4}$ and after $30 \mathrm{~min}$ with $212 \mathrm{mg}(1.0$ $\mathrm{mmol}$ ) of 9 . After $48 \mathrm{~h}$ at $55^{\circ} \mathrm{C}$ hydrolytic workup gave an $82 \%$ yield of $3,3^{\prime}$-dimethylbiphenyl.

Hydrodesulfurization of 3,7-Dimethyldibenzothiophene (10). A reaction mixture of $560 \mathrm{mg}(2.03 \mathrm{mmol})$ of (COD) ${ }_{2} \mathrm{Ni}$ and $220 \mathrm{mg}(2.03$ $\mathrm{mmol}$ ) of $2,2^{\prime}$-bipyridyl in $15 \mathrm{~mL}$ of THF was treated first with $80 \mathrm{mg}$ $(2.03 \mathrm{mmol})$ of $\mathrm{LiAlH}_{4}$ and then with $212 \mathrm{mg}(1.07 \mathrm{mmol})$ of $\mathbf{1 0}$. After $48 \mathrm{~h}$ at $55^{\circ} \mathrm{C}$ and the usual workup the GLPC analysis showed a $68 \%$ conversion to $4,4^{\prime}$-dimethylbiphenyl but none of the $3,3^{\prime}$ isomer.

Ring Contraction of Sulfur Heterocycles with $\left(2,2^{\prime}\right.$-Bipyridyl $)(1,5$ cyclooctadiene)nickel (1). (a) Phenoxathiin (11). A violet solution of an equimolar mixture of (COD) ${ }_{2} \mathrm{Ni}$ and $2,2^{\prime}$-bipyridyl in THF (10
$\mathrm{mL} / 1.5 \mathrm{mmol}$ of 1) was treated with phenoxathiin and the resulting mixture heated at $55^{\circ} \mathrm{C}$ for $48 \mathrm{~h}$. The cooled reaction mixture was treated with glacial acetic acid, and the organic products were isolated in the usual way. For four reactions having the following ratios of 11:1, namely, $1: 1,1: 2,1: 3$, and $1: 4$, the corresponding conversions to dibenzofuran, as determined by GLPC analysis, were $15 \%, 79 \%, 81 \%$, and $78 \%$. Thus, a $1: 2$ ratio of $11: 1$ was most satisfactory. Also, the side production of diphenyl ether increased as the ratio of 11:1 changed: 1:1, $1 \% ; 1: 2,3 \%$; and $1: 3,11 \%$

(b) Phenothiazine (12). Similar to the procedure in section a, the interaction of $3.15 \mathrm{mmol}$ of $\mathbf{1}$ in $20 \mathrm{~mL}$ of THF with $1.5 \mathrm{mmol}$ of $\mathbf{1 2}$ yielded a $75 \%$ conversion to carbazole and a $5 \%$ conversion to diphenylamine.

(c) Thianthrene (13). Similar to the procedure in section a, the reaction between $3.2 \mathrm{mmol}$ of 1 and $1.3 \mathrm{mmol}$ of 13 gave $55 \%$ dibenzothiophene, $15 \%$ biphenyl, and $30 \% 13$.

Hydrodesulfurization of Sulfur Heterocycles (Table III). (a) Phenoxathiin (11). To a violet solution of $2.2 \mathrm{mmol}$ each of (COD) ${ }_{2} \mathrm{Ni}$ and $2,2^{\prime}$-bipyridyl in $20 \mathrm{~mL}$ of THF was added $2.2 \mathrm{mmol}$ of $\mathrm{LiAlH}_{4}$. After $60 \mathrm{~min}$ at $25^{\circ} \mathrm{C} 1.0 \mathrm{mmol}$ of 11 was added. The reaction was allowed to proceed for $24 \mathrm{~h}$ at $25-30^{\circ} \mathrm{C}$. The usual workup and GLPC analysis showed a mixture of $92 \%$ diphenyl ether, $3 \%$ dibenzofuran, and $5 \% 11$.

(b) Phenothiazine (12). A violet solution of $3.9 \mathrm{mmol}$ of 1 in $20 \mathrm{~mL}$ of THF was treated with $6.0 \mathrm{mmol}$ of $\mathrm{LiAlH}_{4}$. After $60 \mathrm{~min}$ of stirring, $1.8 \mathrm{mmol}$ of 12 was added and the mixture heated for $48 \mathrm{~h}$ at $55^{\circ} \mathrm{C}$. The usual workup gave $65 \%$ diphenylamine, $5 \%$ carbazole, and $30 \% 12$.

(c) Thianthrene (13). A violet solution of $3.0 \mathrm{mmol}$ of 1 in $20 \mathrm{~mL}$ of THF was treated with $3.0 \mathrm{mmol}$ of $\mathrm{LiAlH}_{4}$, and then $1.4 \mathrm{mmol}$ of 13 was added. After $48 \mathrm{~h}$ at $55^{\circ} \mathrm{C}$ and the usual workup, the following products were found: $15 \%$ biphenyl, $5 \%$ dibenzothiophene, benzene, and 13

Acknowledgment. We owe the opportunity to conduct this investigation to the support provided by Grants DE-FG2281 PC40782 and 84PC70786 from the U.S. Department of Energy. We are appreciative of pertinent experimental data provided by the work of Dr. Andrzej M. Piotrowski and Stephen R. Sexsmith.

Registry No. 1, 55425-72-4; 3, 132-65-0; 3a, 92-52-4; 9, 1207-15-4; 9a, 612-75-9; 10, 1136-85-2; 10a, 613-33-2; 11, 262-20-4; 11a, 132-64-9; 11b, 101-84-8; 12, 92-84-2; 12a, 86-74-8; 12b, 122-39-4; 13, 92-85-3; benzene, 71-43-2; ethylenediamine, 107-15-3; 2,2'-bipyridyl, 366-18-7; hexamethylphosphorus triamide, $680-31-9 ; N, N, N, N^{\prime}$-tetramethylethylenediamine, 110-18-9; pyridine, 110-86-1; $N, N^{\prime}$-dimethylpiperazine, 106-58-1; 1,8-bis(dimethylamino)naphthalene, 20734-58-1; 1,10phenanthroline, 66-71-7; 4-(dimethylamino)pyridine, 1122-58-3.

\title{
Do Carbenium Ion Additions toward Alkenes Proceed via $\pi$ Complexes? A Stereochemical Investigation
}

\author{
Rudolf Pock, Herbert Mayr, ${ }^{*}$ Monika Rubow, and Eberhard Wilhelm \\ Contribution from the Institut für Chemie der Medizinischen Universität zu Lübeck, \\ D-2400 Lübeck 1, Federal Republic of Germany. Received May 13, 1986
}

\begin{abstract}
Lewis-acid-catalyzed addition reactions of diarylmethyl chlorides with $(E)$ - and $(Z)$-2-butene yield the addition products $3 \mathrm{a}$ ( $>84 \%$ anti selectivity) and the products $5-7$, which are formed via $1,2-\mathrm{H}$ and $1,2-\mathrm{CH}_{3}$ shifts. The Markovnikov addition products $3 \mathrm{~b}$ are generated exclusively from the corresponding reactions with the $E, Z$-isomeric $\beta$-methylstyrenes $2 \mathrm{~b}$. While the $E$ isomer $\mathbf{t}-\mathbf{2 b}$ gives the anti adducts $\mathbf{t}-\mathbf{3 b}$ predominantly, $(Z)-\beta$-methylstyrene reacts with low stereoselectivity. In all cases, the yield of anti adducts increases with increasing stability of the attacking diarylcarbenium ion and decreasing solvent polarity. These observations are interpreted in terms of partially bridged intermediates which are attacked by nucleophiles from the backside.
\end{abstract}

\section{Introduction}

Electrophilic additions to carbon-carbon double bonds have been studied in great detail. ${ }^{1} \quad \mathrm{~A}$ wide variety of mechanisms has

(1) (a) Fahey, R. C. In Topics in Stereochemistry; Eliel, E. L., Allinger, N. L., Eds.; Interscience: New York, 1968; Vol. 3, p 237. (b) Schmid, G H.; Garratt, D. G. In The Chemistry of Double-Bonded Functional Groups; Patai, S., Ed.; Wiley: New York, 1977; Supplement A, Part 2, p 725. (c) De la Mare, P. B. D.: Bolton, R. Electrophilic Additions to Unsaturated Systems; Elsevier: Amsterdam, 1982. (d) Freeman, F. Chem. Rev, 1975, 75. 439. been detected, and the stereochemical course ranges from high anti ${ }^{2 a-c}$ or $\operatorname{syn}^{2 d}$ stereoselectivity to a complete loss of stereochemical information ${ }^{2 e}$ (Scheme I). Concerted and stepwise mechanisms have been reported, $, 1,2$ and the latter processes might

(2) (a) Schmid, G. H.; Csizmadia, V. M.; Nowlan, V. J.; Garratt, D. G. Can. J. Chem. 1972, 50, 2457. (b) Schmid, G. H.; Nowlan, V. J. Can. J. Chem. 1976, 54, 695. (c) Rolston, J. H.; Yates, K. J. Am. Chem. Soc. 1969, 91, 1469. (d) Dewar, M. J. S.; Fahey, R. C. J. Am. Chem. Soc. 1963, 85, 3645. (e) Rolston, J. H.; Yates, K. J. Am. Chem. Soc. 1969, $91,1477$. 


\section{Scheme I}

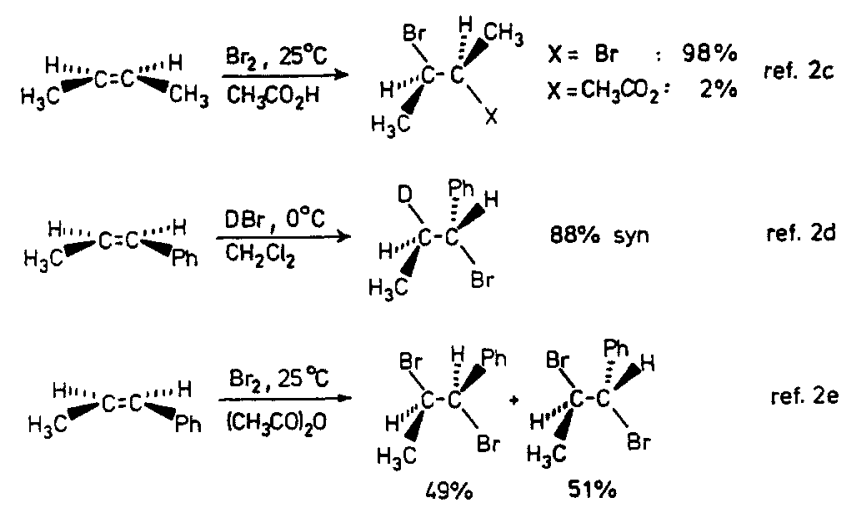

Scheme II

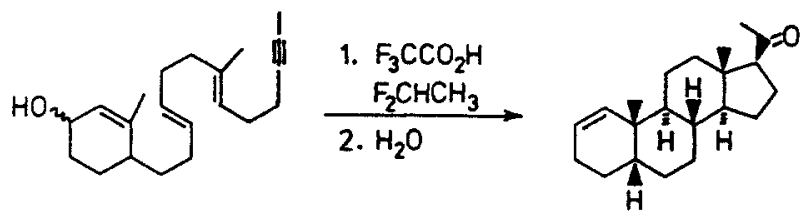

Table I. Relative Alkene/Alkyne Reactivities toward Electrophiles ${ }^{3}$

\begin{tabular}{|c|c|c|c|}
\hline electrophile & conditions & $\begin{array}{c}k \text { (styrene)/ } \\
k \text { (phenylacetylene) }\end{array}$ & $\begin{array}{c}k(1 \text {-hexene }) / \\
k(1 \text {-hexyne })\end{array}$ \\
\hline$\overline{\mathrm{H}^{+}}$ & $\begin{array}{l}48 \% \mathrm{H}_{2} \mathrm{SO}_{4} \\
25^{\circ} \mathrm{C}\end{array}$ & 0.65 & 3.6 \\
\hline $\mathrm{Ph}_{2} \mathrm{CH}^{+}$ & $\begin{array}{r}\mathrm{Ph}_{2} \mathrm{CHCl} / \mathrm{ZnCl}_{2}, \\
\mathrm{CH}_{2} \mathrm{Cl}_{2}, 40^{\circ} \mathrm{C}\end{array}$ & 3.8 & \\
\hline $\mathrm{Br}_{2}$ & $\begin{array}{l}\mathrm{CH}_{3} \mathrm{CO}_{2} \mathrm{H} \\
25^{\circ} \mathrm{C}\end{array}$ & 2600 & 65000 \\
\hline $\mathrm{Cl}_{2}$ & $\underset{25^{\circ} \mathrm{C}}{\mathrm{CH}_{3} \mathrm{CO}_{2} \mathrm{H}}$ & 720 & 530000 \\
\hline$p-\mathrm{ClC}_{6} \mathrm{H}_{4} \mathrm{SCl}$ & $\begin{array}{c}\mathrm{Cl}_{2} \mathrm{CHCHCl}{ }_{2}{ }^{\circ} \mathrm{C} \\
\text {, }\end{array}$ & 186 & 84 \\
\hline
\end{tabular}

proceed via bridged or nonbridged transition states. Modena et al. suggested that electrophiles which react via bridged intermediates may be recognized by high alkene/alkyne reactivity ratios (halogens and sufenyl halides). ${ }^{3}$ On the other hand, a low alkene/alkyne reactivity ratio was considered to indicate that bridging is energetically unimportant. Since carbenium ions, like protons, show similar reactivities toward alkenes and alkynes (Table I), these electrophiles were suggested to react via nonbridged intermediates. ${ }^{3}$

This conclusion is in contrast to Dewar's perception of $\pi$ complexes as intermediates in carbenium ion additions to $\mathrm{CC}$ double bonds. ${ }^{4}$ Dewar and Reynolds rationalized the high anti stereoselectivity of biomimetic polyene cyclizations ${ }^{5}$ by the intermediacy of olefin-carbenium ion $\pi$ complexes (Scheme II). ${ }^{4}$ The stepwise mechanism associated with this proposition is in accord with other recent mechanistic studies. ${ }^{6}$

In spite of the great interest in the mechanism of these intramolecular carbenium ion additions, stereochemical studies of intermolecular carbenium ion additions have not yet been carried out. This situation is surprising since more than 20 years ago Dewar claimed that "there is dire need for data concerning the stereochemistry of additions to olefins where the primary reagent is a carbonium ion."

(3) Melloni, G.; Modena, G.; Tonellato, U. Acc. Chem. Res. 1981, 14, 227 (4) Dewar, M. J. S.; Reynolds, C. H. J. Am. Chem. Soc. 1984, 106, 1744 and references cited therein.

(5) (a) Johnson, W. S. Angew. Chem. 1976, 88, 33; Angew. Chem., Int. Ed Engl 1976, 15, 9. (b) Johnson, W. S. Bioorg. Chem. 1976, 5, 51.

(6) (a) Nishizawa, M.: Takenaka, H.: Hayoshi, Y. J. Am. Chem. Soc. 1985, I07, 522. (b) Nishizawa, M.; Takenaka, H.; Hayoshi, Y.J. Org. Chem. 1986, 5l, 806. See however: Bartlett, P. A. In Asymmetric Synthesis; Morrison, J. D., Ed.; Academic: Orlando, 1984; Vol. III, Chapter 5.

(7) Dewar, M. J. S.; Fahey, R. C. Angew. Chem. 1964, 76, 320; Angew. Chem., Int. Ed. Engl. 1964, 3, 245.

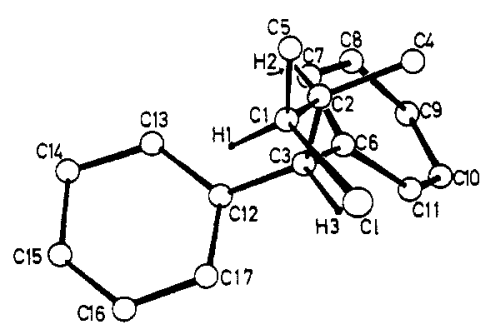

Figure 1. X-ray structure of $(S, S)$-3-chloro-2-methyl-1,1-diphenylbutane $\left(\mathbf{t}-\mathbf{3} \mathbf{a}^{\prime}\right)$.

Scheme III

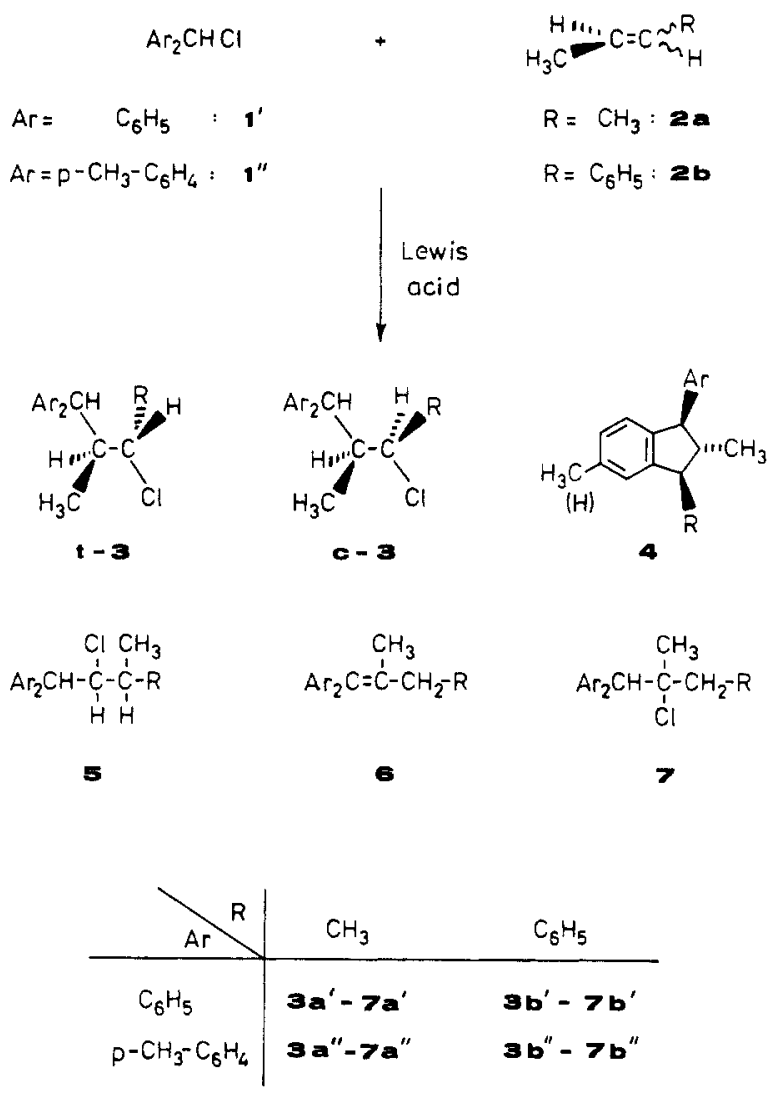

We have recently developed methods to selectively generate $1: 1$ addition products via Lewis-acid-catalyzed reactions of alkyl halides with alkenes ${ }^{8}$ and report now on the stereochemistry of these reactions.

\section{Reaction Products and Structure Determination}

The diarylmethyl chlorides $\mathbf{1}^{\prime}$ and $\mathbf{1}^{\prime \prime}$ react with the $E, Z$ isomeric 2-butenes (2a) and 1-phenylpropenes (2b) in the presence of various Lewis acids to give [1:1] products in high yield (Scheme III).

Table II shows that both isomeric 1-phenylpropenes $(\mathbf{c}, \mathbf{t}-\mathbf{2 b})$ react with $\mathbf{1}^{\prime}$ and $\mathbf{1}^{\prime \prime}$ to give exclusively the regular Markovnikov adducts $\mathbf{c , t - 3 b}$ when $\mathrm{ZnCl}_{2} / \mathrm{Et}_{2} \mathrm{O}$ is used as the catalyst. When

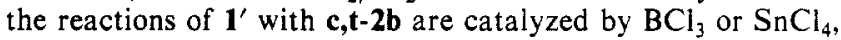
the addition products $3 \mathbf{b}^{\prime}$ are accompanied by approximately $20 \%$ of the indane $4 b^{\prime}$. This compound is the sole product of the $\mathrm{TiCl}_{4}$-catalyzed reaction and of the $\mathrm{ZnCl}_{2}$-catalyzed reaction at $40^{\circ} \mathrm{C} .{ }^{9}$

The stereoselectivities of these reactions differ considerably. While trans- $\beta$-methylstyrene ( $\mathbf{t}-\mathbf{2 b}$ ) yields the anti adducts $\mathbf{t}-\mathbf{3 b}$

(8) (a) Mayr, H. Angew. Chem, 1981, 93, 202: Angew. Chem., Int. Ed Engl. 1981, 20, 184. (b) Mayr, H.; Striepe, W. J. Org. Chem. 1983, 48, 1159.

(9) (a) Marcuzzi, F.; Melloni, G.; Modena, G. J. Org. Chem. 1979, 44, 3022. (b) Marcuzzi, F.; Melloni, G. J. Chem. Res. Synop. 1979, 184; J. Chem. Res. Miniprint 1979, 2287.

(10) Mayr, H.; Striepe, W. J. Org. Chem. 1985, 50, 2995 
Table II. Products from Lewis-Acid-Catalyzed Reactions of the Diarylmethyl Chlorides $\mathbf{1}^{\prime}$ and $\mathbf{1}^{\prime \prime}$ with Cis/Trans Isomeric $\mathrm{Alkenes}$ in $\mathrm{CH}_{2} \mathrm{Cl}_{2}$ at $-78^{\circ} \mathrm{C}$

\begin{tabular}{|c|c|c|c|c|c|c|c|c|c|c|c|}
\hline \multirow[b]{2}{*}{$\mathrm{Ar}$} & \multirow[b]{2}{*}{$\mathrm{Ar}_{2} \mathrm{CHCl}$} & \multirow[b]{2}{*}{ alkene } & \multirow{2}{*}{\multicolumn{2}{|c|}{ Lewis acid }} & \multicolumn{6}{|c|}{ products, $\%^{a}$} & \multirow[b]{2}{*}{ anti/syn } \\
\hline & & & & & $t-3$ & c-3 & 4 & 5 & 6 & 7 & \\
\hline \multirow[t]{16}{*}{$\mathrm{Ph}$} & \multirow[t]{16}{*}{$\mathbf{1}^{\prime}$} & & \multirow[t]{4}{*}{$t-2 a$} & $\mathrm{ZnCl}_{2}{ }^{b}$ & 72.6 & 3.3 & - & 2.8 & 6.7 & 14.6 & 22 \\
\hline & & & & $\mathrm{BCl}_{3}$ & 64.1 & 9.0 & - & 5.6 & - & 21.3 & 7.1 \\
\hline & & & & $\mathrm{SnCl}_{4}$ & 69.4 & 6.4 & - & 3.2 & - & 21.0 & 11 \\
\hline & & & & $\mathrm{TiCl}_{4}$ & 96.1 & - & - & - & - & 3.9 & $>300$ \\
\hline & & \multirow[t]{4}{*}{$=$} & \multirow[t]{4}{*}{$c-2 a$} & $\mathrm{ZnCl}_{2}^{b}$ & 6.8 & 42.6 & - & 3.4 & 4.5 & 42.3 & 6.3 \\
\hline & & & & $\mathrm{BCl}_{3}$ & 5.9 & 29.9 & - & 3.0 & - & 61.2 & 5.1 \\
\hline & & & & $\mathrm{SnCl}_{4}$ & 2.9 & 30.8 & - & 0.84 & 0.45 & 65.0 & 11 \\
\hline & & & & $\mathrm{TiCl}_{4}$ & 2.9 & 75.6 & - & - & 1.1 & 20.4 & 26 \\
\hline & & \multirow{4}{*}{$\widehat{八}_{P h}$} & \multirow{4}{*}{$t-2 b$} & $\mathrm{ZnCl}_{2}^{b}$ & 98.4 & 1.60 & - & - & - & - & 62 \\
\hline & & & & $\mathrm{BCl}_{3}$ & 69.7 & 10.3 & 20 & - & - & - & 6.8 \\
\hline & & & & $\mathrm{SnCl}_{4}$ & 75.2 & 4.8 & 20 & - & - & - & 16 \\
\hline & & & & $\mathrm{TiCl}_{4}$ & - & - & 100 & - & - & - & - \\
\hline & & & $c-2 b$ & $\mathrm{ZnCl}_{2}^{b}$ & 80.5 & 19.5 & - & - & - & - & 0.24 \\
\hline & & & & $\mathrm{BCl}_{3}$ & $56-62^{c}$ & $27-21^{c}$ & 17 & - & - & - & $0.33-0.47$ \\
\hline & & & & $\mathrm{SnCl}_{4}$ & 70.2 & 12.8 & 17 & - & - & - & 0.18 \\
\hline & & & & $\mathrm{TiCl}_{4}$ & - & - & 100 & - & - & - & - \\
\hline \multirow{4}{*}{$\mathrm{CH}_{3}=$} & \multirow[t]{4}{*}{$1^{\prime \prime}$} & & $t-2 a$ & $\mathrm{ZnCl}_{2}^{b}$ & $86^{d}$ & $--^{d}$ & $-d$ & $-d$ & $4.5^{d}$ & $--^{d}$ & $>20$ \\
\hline & & & $c-2 a$ & $\mathrm{ZnCl}_{2}{ }^{b}$ & $7.6^{d}$ & $63^{d}$ & $-d$ & $-d$ & $6.9^{d}$ & $10.4^{d}$ & 8 \\
\hline & & & $t-2 b$ & $\mathrm{ZnCl}_{2}{ }^{b}$ & 100 & - & - & - & - & - & $>300$ \\
\hline & & & $c-2 b$ & $\mathrm{ZnCl}_{2}^{6}$ & 68.4 & 31.6 & - & - & - & - & 0.46 \\
\hline
\end{tabular}

${ }^{a}$ The product distributions described in this table have been determined by HPLC (exception: $\mathbf{1}^{\prime \prime}+\mathbf{c , t - 2 a}$ ). A dash indicates $\leq 0.3 \%$ and $\leqslant 3 \%$ for the reactions monitored by ${ }^{1} \mathrm{H} N M R$. ${ }^{b} \mathrm{ZnCl}_{2}$ was used as diethyl ether complex; ${ }^{10} \mathrm{ZnCl}_{2}: \mathrm{Et}_{2} \mathrm{O}=0.636$. ${ }^{c}$ Isomerization $\mathbf{c}-2 \mathbf{b} \rightarrow \mathrm{t}-2 \mathbf{b}$ detectable. ${ }^{d}$ Determined by ${ }^{1} \mathrm{H}$ NMR.

Table III. 'H NMR Spectroscopic Data of the Diasteromeric Addition Products c,t-3a,b

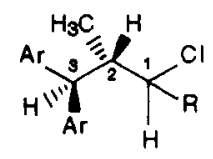

\begin{tabular}{|c|c|c|c|c|c|c|c|c|}
\hline & solvent & $1-\mathrm{H}$ & $2-\mathrm{H}$ & $3-\mathrm{H}$ & $\mathrm{R}$ & $2-\mathrm{CH}_{3}$ & $J_{1,2}$ & $J_{2,3}$ \\
\hline$t-3 a^{\prime}$ & $\mathrm{CDCl}_{3}$ & 4.00 & 2.51 & 3.88 & 1.47 & 0.92 & 1.7 & 11.4 \\
\hline$c-3 \mathbf{a}^{\prime}$ & $\mathrm{CCl}_{4}$ & 4.08 & 2.88 & 3.62 & 1.30 & 0.93 & 3.4 & 11.2 \\
\hline$t-3 a^{\prime \prime}$ & $\mathrm{CDCl}_{3}$ & 4.10 & 2.45 & 3.80 & 1.47 & 0.91 & 1.7 & 11.4 \\
\hline c-3a" & $\mathrm{CCl}_{4}$ & 4.07 & 2.80 & 3.50 & 1.27 & 0.90 & 3.2 & 11.1 \\
\hline $\mathbf{t}-\mathbf{3} \mathbf{b}^{\prime}$ & $\mathrm{CDCl}_{3}$ & 4.97 & 2.79 & 4.02 & & 0.83 & 2.1 & 11.2 \\
\hline$c-3 b^{\prime}$ & $\mathrm{CDCl}_{3}$ & 5.02 & 3.16 & 3.65 & & 0.86 & 4.9 & 10.0 \\
\hline$t-3 b^{\prime \prime}$ & $\mathrm{CCl}_{4}$ & 4.92 & 2.62 & 3.92 & & 0.82 & 2.0 & 10.7 \\
\hline$c-3 b^{\prime \prime}$ & $\mathrm{CCl}_{4}$ & 4.98 & 3.07 & 3.58 & & 0.80 & 4.5 & 9.5 \\
\hline
\end{tabular}

predominantly or exclusively, the reactions of $\mathbf{c}-2 \mathbf{b}$ proceed with low stereoselectivity. The major product $(\mathbf{t}-\mathbf{3 b})$ is identical with that obtained in the trans-phenylpropene additions. It was demonstrated that the product ratios were identical at low and high degree of conversion and did not alter when the mixture was allowed to stand with the Lewis acids after completion of the reaction.

The corresponding reactions with the 2-butenes c,t-2a yield the 1,2- $\mathrm{H}$ and $1,2-\mathrm{CH}_{3}$ shifted products $5-7$ in addition to the regular adducts c,t-3a. In contrast to the behavior of the $\beta$-methylstyrenes, both 2-butene isomers react with high anti stereoselectivity (anti/syn $\geq 84: 16$ ).

The stereochemical assignment of the diastereomeric adducts $\mathbf{3 a}$ and $\mathbf{3 b}$ is based on the $\mathrm{X}$-ray analysis of $\mathbf{t}-\mathbf{3} \mathbf{a}^{\prime}$, the major product obtained from the reaction of diphenylmethyl chloride $\mathbf{1}^{\prime}$ with trans-butene t-2a (Figure 1). The dihedral angles $\mathrm{H}_{1}-\mathrm{C}_{1}-\mathrm{C}_{2}-\mathrm{H}_{2}$ $\approx 60^{\circ}$ and $\mathrm{H}_{2}-\mathrm{C}_{2}-\mathrm{C}_{3}-\mathrm{H}_{3} \approx 180^{\circ}$ derived from Figure 1 are in accord with the corresponding $\mathrm{HH}$ coupling constants of 1.7 and $11.4 \mathrm{~Hz}$. The configurational assignments of the analogous products $3 \mathbf{a}^{\prime \prime}, \mathbf{3} \mathbf{b}^{\prime}$, and $\mathbf{3} \mathbf{b}^{\prime \prime}$ are based on the analogy of their ${ }^{1} \mathrm{H}$ NMR spectra (Table III). Whereas $J_{2,3}$ is of similar magnitude in all compounds, $J_{1,2}$ is approximately twice as large in the $\mathrm{c}$ than in the $t$ isomers. While $2-\mathrm{H}$ is more shielded in the $t$ isomers, $3-\mathrm{H}$ absorbs at higher field in the $\mathrm{c}$ isomers.

\section{Mechanistic Study and Discussion}

In accord with previous studies, ${ }^{3,8}$ it is assumed that the diarylmethyl chlorides $\mathbf{1}$ ionize to give the diarylcarbenium ions $\mathbf{8}$, which attack the alkenes 2 with formation of the cations 9 (Scheme IV). Since different product mixtures are obtained from stereoisomeric alkenes, one must exclude the intermediacy of long-lived freely rotating cations 9 . Ion-pair effects cannot account for the observed stereoselectivities, as their operation would require syn selectivity. ${ }^{1.7}$ The observation that the addition rates of diarylcarbenium ions to alkenes (eq l) are independent of the nature and the concentration of the counterions ${ }^{11}$ excludes the operation of an Ad-E3-type mechanism.

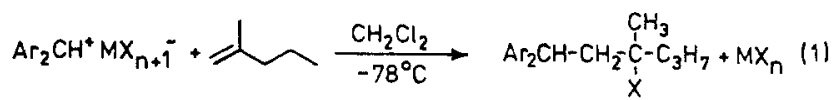

To account for the stereoselectivity, we assume that 9 is at least partially bridged, as indicated by the dotted lines in $9 \alpha-9 \zeta$ and that the nucleophiles attack 9 from the open side. Conformer $9 \alpha$, which is initially formed from $\mathbf{8}^{\prime}$ and trans-butene (t-2a), is trapped faster by $\mathrm{Cl}^{-}$to give $\mathrm{t}-3 \mathrm{a}^{\prime}$ than it can undergo a $60^{\circ}$ rotation to

(11) Schneider, R.; Grabis, U.; Mayr, H. Angew. Chem. 1986, 98, 94; Angew. Chem., Int. Ed. Engl. 1986, 25, 89 


\section{Scheme IV}

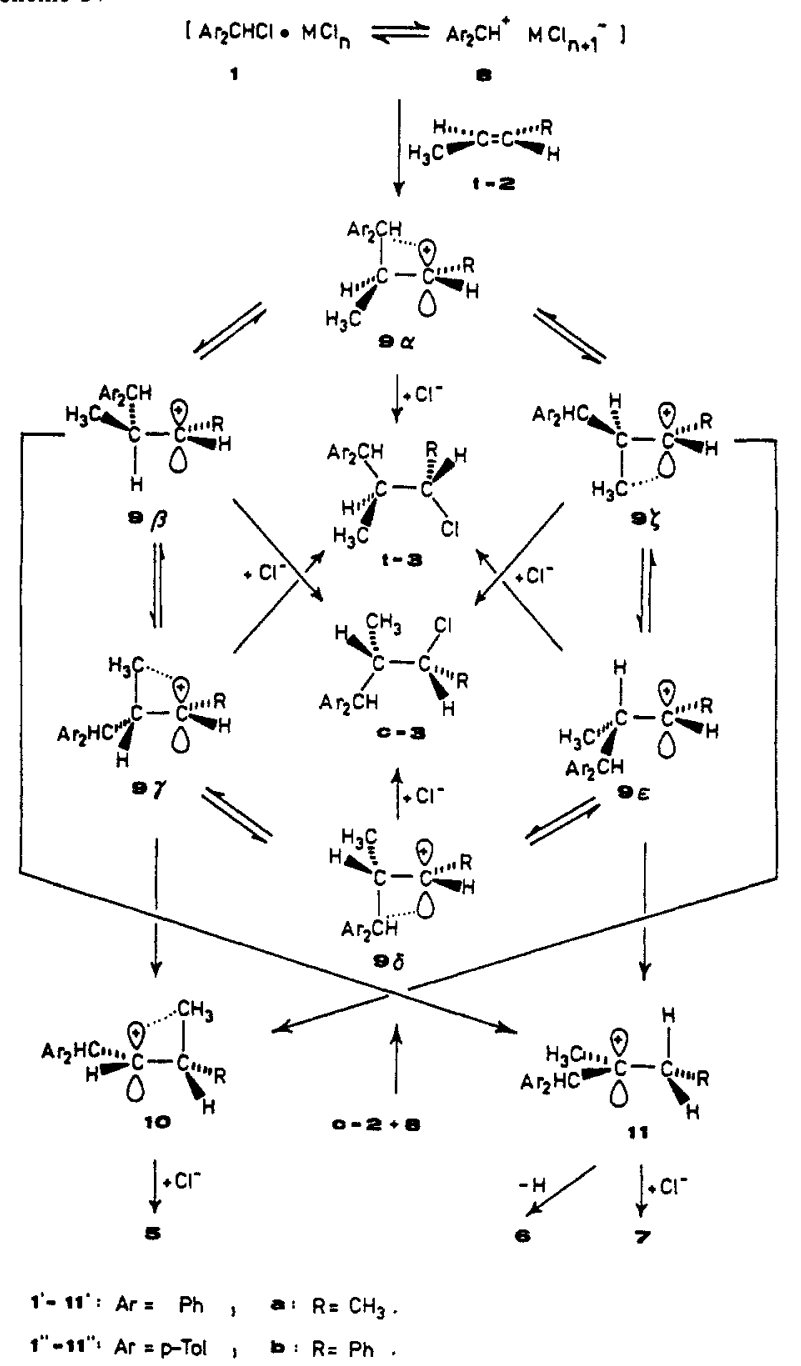

give $9 \beta$ or $9 \zeta$. These conformers may be attacked by $\mathrm{Cl}^{-}\left(\rightarrow \mathrm{c}-3 \mathrm{a}^{\prime}\right)$ or undergo $1,2-\mathrm{H}$ or $1,2-\mathrm{CH}_{3}$ shifts to form 11 and 10 , the precursors of 6,7 , and 5 . We assume that the low yield of 5 compared with 6 and 7 rather reflects the higher rearrangement tendency of $9 \beta(\rightarrow$ tertiary carbenium ion) compared with $9 \zeta(\rightarrow$ secondary carbenium ion) than the preferred mode of rotation of $9 \alpha$. Cation $9 \delta$ is conformationally more strained than $9 \alpha$ and is therefore expected to rotate faster. As a consequence, the reaction of $\mathbf{8}^{\prime}$ with $\mathbf{c - 2 a}$ yields less of the anti adduct $\left(\mathbf{c}-3 \mathbf{a}^{\prime}\right)$ and a higher percentage of $\mathrm{H}$-shifted products (Table II).

Comparison of the $\mathrm{ZnCl}_{2}$-catalyzed reactions of $\mathbf{1}^{\prime}$ and $\mathbf{1}^{\prime \prime}$ with the isomeric 2-butenes shows that the better stabilized ditolylcarbenium ion yields higher amounts of anti adducts and reduced percentages of rearranged products. These data indicate the higher bridging ability of $\mathrm{Tol}_{2} \mathrm{CH}$ compared with $\mathrm{Ph}_{2} \mathrm{CH}$. While this interpretation is in accordance with the qualitative VB interpretation of hyperconjugation, it contradicts the conclusion obtained from quantitative MO calculations. Computations with the STO-3G minimal basis set indicated that the energy difference between bridged and nonbridged species $12 \mathrm{a}$ and $12 \mathrm{~b}$ is not significantly affected by the nature of $X .^{12}$ The cations 9 , which
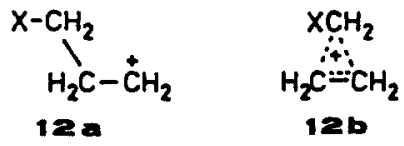

are obtained from the addition of $\mathbf{8}$ to the phenylpropenes $\mathbf{c , t}-\mathbf{2 b}$,

(12) Saunders, M.; Chandrasekhar, J.; Schleyer, P. v. R. In Rearrangements in Ground and Excited States; de Mayo, P., Ed.; Academic: New York, 1980; Vol. I. p 1.
Table IV. Influence of the Solvent on the Stereochemistry of Benzhydryl Chloride $\mathbf{1}^{\prime}$ Additions to cis-and trans-Phenylpropene at $-78^{\circ} \mathrm{C}$

\begin{tabular}{|c|c|c|c|c|c|}
\hline \multirow[b]{2}{*}{ alkene } & \multirow[b]{2}{*}{ Lewis acid } & \multirow{2}{*}{$\begin{array}{l}\mathrm{CH}_{2} \mathrm{Cl}_{2} \text { : } \\
\text { petroleum } \\
\text { ether }(\mathrm{v}: \mathrm{v})\end{array}$} & \multicolumn{3}{|c|}{ products, $\%^{a}$} \\
\hline & & & $t-3 b^{\prime}$ & $c-3 b^{\prime}$ & anti/syn \\
\hline \multirow[t]{3}{*}{$t-2 b$} & $\mathrm{SnCl}_{4}$ & $\infty$ & 94.0 & 6.0 & 15.7 \\
\hline & & 4 & 95.5 & 4.5 & 21.2 \\
\hline & & 1 & 96.5 & 3.5 & 27.6 \\
\hline \multirow[t]{3}{*}{$c-2 b$} & $\mathrm{SnCl}_{4}$ & $\infty$ & 84.6 & 15.4 & 0.182 \\
\hline & & 4 & 65.0 & 35.0 & 0.538 \\
\hline & & 1 & 41.8 & 58.2 & 1.39 \\
\hline \multirow[t]{3}{*}{$c-2 b$} & $\mathrm{ZnCl}_{2} \cdot \mathrm{Et}_{2} \mathrm{O}$ & $\infty$ & 80.5 & 19.5 & 0.242 \\
\hline & & 4 & 69.6 & 30.4 & 0.437 \\
\hline & & 1 & 64.2 & 35.8 & 0.558 \\
\hline
\end{tabular}

a The $\mathrm{SnCl}_{4}$-catalyzed reactions gave indane $4 \mathbf{b}^{\prime}$ as side product. The amount of $4 \mathbf{b}^{\prime}$ decreases with decreasing solvent polarity: $\approx 20 \%$ in $\mathrm{CH}_{2} \mathrm{Cl}_{2}, \approx 10 \%$ in $\mathrm{CH}_{2} \mathrm{Cl}_{2}$ /petroleum ether $(4: 1, \mathrm{v}: \mathrm{v}), \approx 5 \%$ in $\mathrm{CH}_{2} \mathrm{Cl}_{2}$ /petroleum ether $(1: 1, v: v)$.

Table V. Influence of Benzyltriethylammonium Chloride (BTEA) on the Stereochemistry of the Benzhydryl Chloride $\mathbf{1}^{\prime}$ Addition to cis-Phenylpropene $\mathbf{c - 2 b}$

\begin{tabular}{lcc}
\hline $\mathbf{c}-2 \mathbf{b}, \mathrm{mmol} / \mathrm{L}$ & 68.2 & 68.6 \\
$\mathbf{1}^{\prime}, \mathrm{mmol}^{\prime} \mathrm{L}$ & 48.8 & 48.2 \\
$\mathrm{SnCl}_{4}, \mathrm{mmol} / \mathrm{L}$ & 8.6 & 8.6 \\
$\mathrm{BTEA}, \mathrm{mmol} / \mathrm{L}$ & 0.0 & 3.4 \\
$\mathbf{c - 3 b ^ { \prime }} / \mathbf{t}-3 \mathbf{b}^{\prime}$ & 0.210 & 0.327 \\
\hline
\end{tabular}

are stabilized by benzylic resonance and therefore do not undergo 1,2-shifts to give rearranged products. The bridging tendency of the $\pi$ delocalized cations $9(R=P h)$ will be lower, and the rotations should be faster. In spite of that, the anti/syn product ratio obtained from the reactions of $\mathbf{1}^{\prime}$ and $\mathbf{1}^{\prime \prime}$ with trans-phenylpropene is rather high, probably because of the low conformational strain in $9 \alpha$. On the other hand, the reactions with cis-phenylpropene $\mathbf{c - 2} \mathbf{b}$ yield only small amounts of anti adducts, because the unfavorable conformers $9 \delta$ rotate faster than they are trapped by the nucleophiles. Both phenylpropene isomers give more anti product with $\mathbf{1}^{\prime \prime}$ than with $\mathbf{1}^{\prime}$, a nalogous to the observations with 2 -butenes (see above).

Analysis of the unreacted phenylpropenes during the course of the reaction showed that the high amount of syn adducts obtained from c-2b cannot be due to cis-trans isomerization of the alkenes prior to addition. Only in the case of the $\mathrm{BCl}_{3}$-catalyzed reaction was a certain degree of stereomutation $(\approx 20 \%$; $\mathbf{c - 2 b} \rightarrow \mathbf{t}-\mathbf{2 b}$ ) detectable. The formation of the indanes 4 has been discussed previously. 9

If the anti/syn ratio or the anti/rearrangement ratio reflects the relative rates of nucleophilic back-side attack and rotation of 9 , this ratio should increase if the lifetime of the cations 9 is reduced by lowering the solvent polarity. Table IV demonstrates that the anti/syn ratio in the reaction of $\mathbf{1}^{\prime}$ with $\mathbf{t}-\mathbf{2 b}$ increases from 15.7 to 27.6 when the solvent $\mathrm{CH}_{2} \mathrm{Cl}_{2}$ is replaced by a $1: 1$ $\mathrm{CH}_{2} \mathrm{Cl}_{2}$ /petroleum ether mixture. The effect is more pronounced in the reaction with the corresponding cis isomer. Whereas only $15 \%$ of the anti adduct is formed in dichloromethane, $58 \%$ of anti product is obtained in a 1:1 mixture of petroleum ether and dichloromethane. A further lowering of solvent polarity was not possible because the mixtures became inhomogeneous. Solubility problems also prevented the preparation of solutions containing high concentrations of $\mathrm{MX}_{n}{ }^{-}$ions. Table $\mathrm{V}$ shows, however, that the presence of benzyltriethylammonium pentachlorostannate increased the yield of anti adduct in the reaction of $\mathbf{1}^{\prime}$ with $\mathbf{c - 2} \mathbf{2}$.

The effect of the nature of the Lewis acid on the product composition cannot easily be explained, because very little data on the kinetic stability of complex anions are available. Heublein et al. reported that $\mathrm{TiCl}_{5}^{-}$transfers $\mathrm{Cl}^{-}$to trityl cations faster than $\mathrm{SnCl}_{5}{ }^{-13}$ The higher anti/syn ratio in the $\mathrm{TiCl}_{4}$-catalyzed reactions with the 2-butenes could thus be explained. It is not 
Scheme V

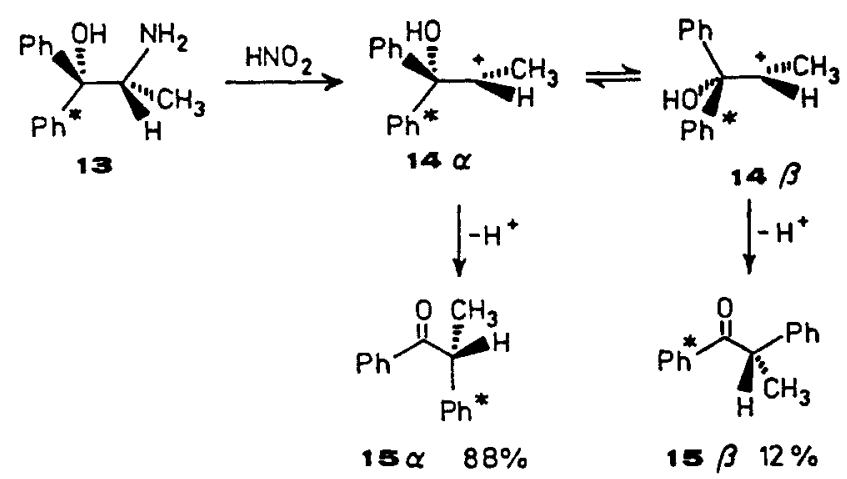

Scheme VI

$$
\begin{array}{llll} 
& = & = & =( \\
k_{\text {rel }}\left(\mathrm{Ph}_{2} \mathrm{CH}^{+}\right)^{17} & 1.0 & 34 & 5800 \\
k_{\text {rel }}\left(\mathrm{Br}_{2}\right)^{18} & 1.0 & 32 & 93
\end{array}
$$

understood, however, why this Lewis acid gives rise to exclusive formation of the indanes 4 in the phenylpropene reactions.

The rationalization of our experimental data by relative rates of rotation and 1,2-migration or nucleophilic back-side attack (conformational control) is precedented in nitrous acid deaminations of acyclic amines. ${ }^{14}$

Collins treated the optically active amine 13 with nitrous acid and isolated the inverted ketone $15 \alpha$, in which the labeled phenyl group migrated, and the ketone $15 \beta$ with retained configuration, in which the unlabeled phenyl was shifted. ${ }^{15 a}$ The product ratio indicated that phenyl migration is more rapid than the $60^{\circ}$ rotation $14 \alpha \rightleftharpoons 14 \beta$, while a $120^{\circ}$ rotation was not detectable, (Scheme V).

In a similar experiment, Collins showed that the rates of phenyl migration and $180^{\circ}$ rotation are of comparable magnitude, when the carbenium center is stabilized by a phenyl group. ${ }^{15 \mathrm{c}}$

The nucleophilic back-side attack at methyl-bridged carbocations has convincingly been demonstrated by Kirmse and coworkers. ${ }^{14,15 d, e}$ When 16 was treated with nitrous acid, the tertiary alcohol 18, which was formed in $15 \%$ yield, showed $98.5 \%$ inversion at the migration origin. ${ }^{16}$ Lewis-acid-catalyzed alkyl halide additions toward alkenes are thus controlled by the same principles as deamination reactions.

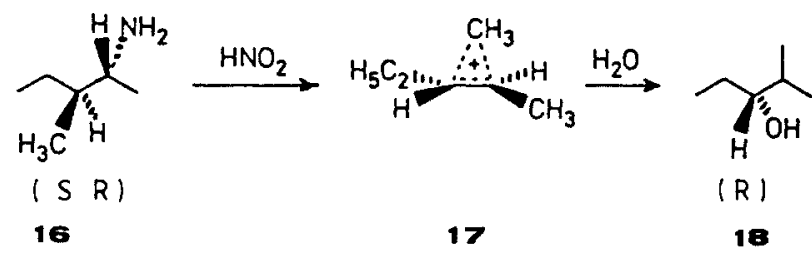

\section{Conclusions}

The stereochemical results reported in this work exclude freely rotating classical carbenium ions as intermediates of the electrophilic alkyl halide additions to alkenes. If strongly bridged intermediates were involved, methyl groups at both olefinic termini should increase the reactivity of the alkenes to a similar degree, as reported for brominations ${ }^{18}$ (Scheme VI). In previous work

(14) Kirmse, W. Topics Curr. Chem. 1979, 80, 125

(15) (a) Benjamin, B. M.; Schaeffer, H. J.; Collins, C. J. J. Am. Chem. Soc. 1957, 79, 6160. (b) Benjamin, B. M.; Wilder, P., Jr.; Collins, C. J. J. Am. Chem. Soc. 1961, 83, 3654. (c) Benjamin, B. M.; Collins, C. J. J. Am. Chem. Soc. 1961, 83, 3662. (d) Kirmse, W.; Loosen, K.; Prolingheuer, E.-C. Chem. Ber. 1980, 113, 129. (e) Kirmse, W.; Ratajczak, H.-J.; Rauleder, G. Chem. Ber. 1977, 110, 2290.

(16) Kirmse, W,; Prolingheuer, E.-C. Chem. Ber. 1980, 113, 104.

(17) (a) Mayr, H.; Pock, R. Chem. Ber. 1986, 119, 2473. (b) Mayr, H.;

Pock, R. Tetrahedron Lett. 1983, 24, 2155. we have shown, however, that diarylcarbenium ion additions to alkenes are accelerated by a factor of 6-50 by methyl groups at the attacked vinylic position and of approximately $10^{4}$ at the new carbenium center. ${ }^{17}$ These data are best explained by weakly bridged intermediates, the geometry of which is strongly dependent on the nature of the alkene substituents.

The previous suggestion of open transition states in carbenium ion additions has been based on the similarity of reaction rates of comparably substituted alkenes and alkynes. ${ }^{3}$ The alkene/ alkyne analogy, however, does not hold for the stereochemistry of these additions. In contrast to the behavior of alkenes, reported in this paper, alkyne 20 reacts with labeled benzyl chloride 19 to give the stereoisomeric vinyl chlorides $\mathbf{2 2 a}$ and $\mathbf{2 2 b}$ in a 1:1 ratio, ${ }^{19}$ in accordance with the intermediacy of the nonbridged

$$
\begin{gathered}
\mathrm{Ph}-\mathrm{CD}_{2} \mathrm{Cl}+\mathrm{Ph}-\mathrm{CH}_{2}-\mathrm{C} \equiv \mathrm{C}-\mathrm{Ph} \\
19
\end{gathered}
$$$$
\mathrm{ZnCl}_{2} \downarrow \mathrm{ClCH}_{2}-\mathrm{CH}_{2} \mathrm{Cl}
$$<smiles>O=C(Cc1ccccc1)C(=Cc1ccccc1)c1ccccc1</smiles>

21

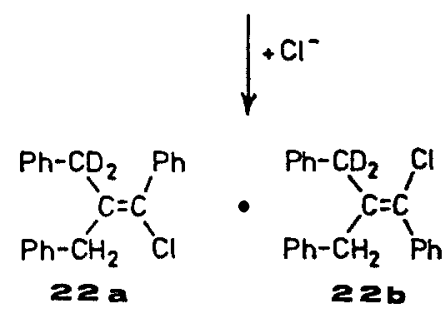

cation 21. If the bridged cations formed via addition of carbenium ions to alkenes are assumed to be of comparable stability as the corresponding nonbridged species, the comparison of alkene and alkyne reaction rates toward carbenium ions does not allow us to differentiate the alternative intermediates.

Do the bridged intermediates, which are required by the stereochemical studies, correspond to Dewar's $\pi$ complexes? No, if these $\pi$ complexes were defined as intermediates separated from the isomeric classical carbenium ions by high barriers, ${ }^{4}$ because this assumption would not account for the observation of rearranged products in the 2-butene additions. Yes, if $\pi$ complexes are considered species on a flat hypersurface which can rapidly interconvert into their slightly less stable nonbridged counterparts. Depending on the substitution pattern, the intermediates will be more or less symmetrical as shown in $\mathbf{2 3}$ and $\mathbf{2 4}$, respectively.

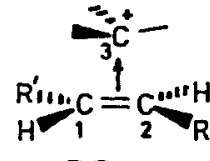

23

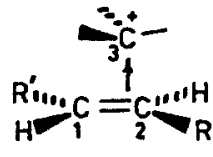

24

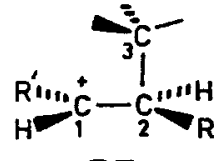

25
Whether a intermediate cationic species with a reduced $\mathrm{C}_{1}-$ $\mathrm{C}_{2}-\mathrm{C}_{3}$ angle is best described as the unsymmetrical $\pi$ complex $\mathbf{2 4}$ or the classical carbenium ion $\mathbf{2 5}$, which is distorted by nonvertical hyperconjugative stabilization, ${ }^{20}$ is a matter of personal taste.

\section{Experimental Section}

General. NMR spectra were obtained on JEOL JNM-PS-100 and Varian XL-200 spectrometers. Chemical shifts are recorded relative to $\left(\mathrm{CH}_{3}\right)_{4} \mathrm{Si}$ as an internal standard. Mass spectra were obtained with $\mathrm{CH}$

(18) Ruasse, M. F.; Dubois, J.-E.; Argile, A. J. Org. Chem. 1979, 44, 1173.

(19) Marcuzzi, F.; Melloni, G. J. Am. Chem. Soc. 1976, 98, 3295.

(20) (a) Traylor, T. G.; Hanstein, W.; Berwin, H. J.; Clinton, N. A.; Brown, R.S. J. Am. Chem. Soc. 1971, 93, 5715. (b) Vogel, P. Carbocation Chemistry; Elsevier: Amsterdam, 1985; p 170. 
4 B MAT and 311 A MAT instruments (Varian). Preparative MPLC was carried out on a $30 \times 2 \mathrm{~cm}$ glass column with LiChroprep Si60,15-25 $\mu \mathrm{m}$ as the stationary phase and petroleum ether (bp 40-60 ${ }^{\circ} \mathrm{C}$ ) as the eluent. Product analysis by HPLC was carried out with a LDC/Milton Roy HPLC system using $250 \times 4.5 \mathrm{~mm}$ steel columns. A LDC/Milton Roy spectromonitor D was used for the detection at 254 $\mathrm{nm}$. The Seebach-Prelog $u, I$ nomenclature ${ }^{21}$ was used to assign the relative stereochemistry of asymmetric centers.

I. Synthesis of 3-7. 1. Diphenylmethyl Chloride $\left(1^{\prime}\right)$ and 2-Butenes c,t-2a. A solution of $\mathrm{BCl}_{3}(6.46 \mathrm{mmol})$ in $3.8 \mathrm{~mL}$ of $\mathrm{CH}_{2} \mathrm{Cl}_{2}$ was added to a precooled $\left(-78{ }^{\circ} \mathrm{C}\right)$ solution of $\mathbf{1}^{\prime}(3.05 \mathrm{~g}, 15.1 \mathrm{mmol})$ and $\mathbf{t}-2 \mathrm{a}(8.00$ g, $143 \mathrm{mmol}$ ) in $50 \mathrm{~mL}$ of $\mathrm{CH}_{2} \mathrm{Cl}_{2}$. After $24 \mathrm{~h}$ of standing at $-78^{\circ} \mathrm{C}$, the mixture was washed with aqueous ammonia and water and dried over $\mathrm{CaCl}_{2}$. The solvent was evaporated, and the residue was separated by MPLC to give a trace of 1,2-dimethyl-3-phenylindane $(\approx 25 \mathrm{mg}, 12.9$ $\mathrm{min}$ ), 5a' (145 mg, 3.7\%, $16.8 \mathrm{~min}), 7 \mathrm{a}^{\prime}(430 \mathrm{mg}, 11 \%, 17.8 \mathrm{~min}$ ), and a mixture of $\mathrm{t}-$ and $\mathrm{c}-3 \mathrm{a}^{\prime}(2540 \mathrm{mg}, 65 \%, 18.6 \mathrm{~min})$.

2-Chloro-3-methyl-1,1-diphenylbutane $\left(5 \mathrm{a}^{\prime}\right)$ : $\mathrm{mp} 87-88^{\circ} \mathrm{C}$ (petroleum ether); ${ }^{1} \mathrm{H}$ NMR $\left(\mathrm{CDCl}_{3}\right) \delta 0.73(\mathrm{~d}, J=6.7 \mathrm{~Hz}, 3 \mathrm{H}), 0.95(\mathrm{~d}, J$ $=6.8 \mathrm{~Hz}, 3 \mathrm{H}), 2.00(\mathrm{~m}, 1 \mathrm{H}), 2.93(\mathrm{t}, J \approx 7.5 \mathrm{~Hz}, 1 \mathrm{H}), 5.38(\mathrm{~d}, J=$ $7.8 \mathrm{~Hz}, 1 \mathrm{H}), 7.08-7.30(\mathrm{~m}, 10 \mathrm{H}) ;{ }^{13} \mathrm{C} \mathrm{NMR}\left(\mathrm{CDCl}_{3}\right) \delta 18.65(\mathrm{q}), 21.67$ (q), 29.61 (d), 60.52 (d), 65.39 (d), 126.71 (d), 127.44 (d), 127.53 (d), 127.93 (d), 128.22 (d), 129.90 (d), 138.20 (s), 140.77 (s); mass spectrum $(70 \mathrm{eV}), \mathrm{m} / z$ (relative intensity) $260,258\left(2,6, \mathrm{M}^{+}\right), 91(100)$.

2-Chloro-2-methyl-1,1-diphenylbutane $\left(7 \mathrm{a}^{\prime}\right): \mathrm{mp} 39^{\circ} \mathrm{C}$ (petroleum ether); ${ }^{1} \mathrm{H}$ NMR $\left(\mathrm{CCl}_{4}\right) \delta 0.95(\mathrm{t}, J \approx 7 \mathrm{~Hz}, 3 \mathrm{H}), 1.47(\mathrm{~s}, 3 \mathrm{H}), 1.82$ (m. $2 \mathrm{H}), 3.97(\mathrm{~s}, 1 \mathrm{H}), 6.97-7.53(\mathrm{~m}, 10 \mathrm{H}) ;{ }^{13} \mathrm{C} \mathrm{NMR}\left(\mathrm{CDCl}_{3}\right) \delta 9.20$ (q), 28.62 (q), 36.75 (t), 62.92 (d), 76.59 (s), 126.74 (d), 128.03 (d), 128.06 (d), 130.06 (d), 130.19 (d), 130.22 (d), 140.77 (s), 140.87 (s)

l-3-Chloro-2-methyl-1,1-diphenylbutane (t-3a): $\mathrm{mp} 83-84^{\circ} \mathrm{C}$ (pentane); ${ }^{1} \mathrm{H}$ NMR, see Table III; ${ }^{13} \mathrm{C}$ NMR $\delta 11.28$ (q), 23.69 (q), 43.35 (d) 56.51 (d), 60.97 (d), 126.13 (d), 126.32 (d), 127.89 (d), 128.04 (d), 128.47 (d), 128.59 (d), 143.18 (s), 143.43 (s); mass spectrum $(96 \mathrm{eV})$, $m / z$ (relative intensity) $260,258\left(11,37, \mathrm{M}^{+}\right), 168(44), 167(100)$. Anal. Calcd for $\mathrm{C}_{17} \mathrm{H}_{19} \mathrm{Cl}$ : C, 78.90; H, 7.40. Found: C, 78.87; H, 7.30.

Crystal and Data Collection Parameters for t-3a': space group, $P_{2} / c$; $a=899.6(4) \mathrm{pm}, b=1470.1(4) \mathrm{pm}, c=1150.7(4) \mathrm{pm}, \beta=108.3^{\circ}$, $V=1444.9 \times 10^{-24} \mathrm{~cm}^{3}, Z=4, d_{\mathrm{r}}=1.19 \mathrm{~g} / \mathrm{cm}^{3}$. A total of 2766 reflections (2384 independent reflections) was measured on a Philips PW 1100 diffractometer using $\mathrm{AgK} \alpha$ radiation (range $0^{\circ}<\theta \leq 19^{\circ}$ ). The structure was solved and refined with the program system Crystan $22(R$ $\left.=0.120 ; R_{\mathrm{w}}=0.044\right)$

A solution of $\mathrm{ZnCl}_{2}(2.59 \mathrm{~g})$ in diethyl ether $(3.1 \mathrm{~mL})$ and $\mathrm{CH}_{2} \mathrm{Cl}_{2}$ $(6.2 \mathrm{~mL})$ was added to a solution of c-2a $(3.90 \mathrm{~g}, 69.5 \mathrm{mmol})$ in $50 \mathrm{~mL}$ of $\mathrm{CH}_{2} \mathrm{Cl}_{2}$ at $-78^{\circ} \mathrm{C}$. Compound $\mathbf{1}^{\prime}(5.00 \mathrm{~g}, 24.7 \mathrm{mmol})$ dissolved in 20 $\mathrm{mL}$ of $\mathrm{CH}_{2} \mathrm{Cl}_{2}$ was added and allowed to react for $8 \mathrm{~h}$ at $-78^{\circ} \mathrm{C}$. Workup as described above yielded a mixture $(5.40 \mathrm{~g})$ of $\mathrm{c}$ - and $\mathrm{t}-3 \mathrm{a}^{\prime}$, $6 a^{\prime}$, and $7 a^{\prime}\left(1: 0.6: 0.2\right.$ by ${ }^{1} H$ NMR) which was crystallized from ethanol to give $\mathrm{c}-3 \mathrm{a}^{\prime}(2.40 \mathrm{~g}, 38 \%)$ as fine needles.

$u$-3-Chloro-2-methyl-1,1-diphenylbutane $\left(\mathbf{c}-3 \mathrm{a}^{\prime}\right): \mathrm{mp} 79-81^{\circ} \mathrm{C} ;{ }^{1} \mathrm{H}$ NMR see Table III; ${ }^{13} \mathrm{C}$ NMR $\left(\mathrm{CDCl}_{3}\right) \delta 12.13$ (q), 17.81 (q), 43.71 (d), 56.45 (d), 59.85 (d), 126.32 (d), 126.47 (d), 127.47 (d), 127.77 (d), 128.53 (d), 128.80 (d), 142.70 (s), 143.30 (s); mass spectrum $(70 \mathrm{eV})$, $m / z$ (relative intensity) $260,258\left(1.1,3.8, \mathrm{M}^{+}\right), 222(16), 168(34), 167$ (100). Anal. Calcd for $\mathrm{C}_{17} \mathrm{H}_{19} \mathrm{Cl}$ : C, 78.90; H, 7.40. Found: C, 78.90; $\mathrm{H}, 7.40$.

1,1-Diphenyl-2-methyl-1-butene (6a'), a component of this reaction mixture, was independently synthesized by treating t-3a' $(708 \mathrm{mg}, 2.74$ $\mathrm{mmol})$ with $\mathrm{ZnCl}_{2}(2.8 \mathrm{~g})$ and diethyl ether $(3.3 \mathrm{~mL})$ in $\mathrm{CH}_{2} \mathrm{Cl}_{2}(6.7$ $\mathrm{mL}$ ) for 4 days at $20^{\circ} \mathrm{C}$. The catalyst was washed out with aqueous ammonia, and the organic layer was dried and distilled to give $6 \mathrm{a}^{\prime}(489$ $\mathrm{mg}, 80 \%$ ) as a colorless liquid: bp $65-73^{\circ} \mathrm{C}$ (bath) $/ 1.3 \times 10^{-3} \mathrm{mbar}$; ${ }^{1} \mathrm{H} \mathrm{NMR}\left(\mathrm{CCl}_{4}\right) \delta 1.03(\mathrm{t}, J=7.5 \mathrm{~Hz}, 3 \mathrm{H}), 1.77(\mathrm{~s}, 3 \mathrm{H}), 2.15(\mathrm{q}, J$ $=7.5 \mathrm{~Hz}, 2 \mathrm{H}), 7,15(\mathrm{~s}, 10 \mathrm{H})$. Anal. Calcd for $\mathrm{C}_{17} \mathrm{H}_{18}: \mathrm{C}, 91.84 ; \mathrm{H}$, 8.16. Found: C, $91.49 ; \mathrm{H}, 8.07$.

2. Diphenylmethyl Chloride (1') and 1-Phenylpropenes c,t-2b. Compound $\mathrm{t}-2 \mathrm{~b}(0.80 \mathrm{~g}, 6.8 \mathrm{mmol}), \mathrm{ZnCl}_{2}(0.26 \mathrm{~g})$ in $0.3 \mathrm{~mL}$ of diethyl ether, and $1^{\prime}(1.30 \mathrm{~g}, 6.41 \mathrm{mmol})$ were combined in $50 \mathrm{~mL}$ of $\mathrm{CH}_{2} \mathrm{Cl}_{2}$ at -78 ${ }^{\circ} \mathrm{C}$. After $13.5 \mathrm{~h}$ the mixture was worked up as described above to give $u$-1-chloro-2-methyl-1,3,3-triphenylpropane ( $\left(\mathrm{t}-3 \mathrm{~b}^{\prime}\right)(1.23 \mathrm{~g}, 60 \%)$ as long needles: mp 90-91 ${ }^{\circ} \mathrm{C} ;{ }^{1} \mathrm{H}$ NMR, see Table III; ${ }^{13} \mathrm{C}$ NMR $\left(\mathrm{CDCl}_{3}\right) \delta$ 11.19 (q), 45.38 (d), 56.51 (d), 66.40 (d), 126.23 (d), 126.56 (d), 126.92 (d), 127.32 (d), 127.86 (d), 127.98 (d), 128.47 (d), 128.83 (d), 140.82 (s), 143.03 (s), 143.21 (s); mass spectrum $(70 \mathrm{eV}), m / z$ (relative inten-

(21) Seebach, D.; Prelog, V. Angew. Chem. 1982, 94, 696; Angew. Chem., Int. Ed. Eng. 1982, 21, 654.

(22) Burzlaff, H.; Böhme, R.; Gomm, M. Crystan-A Crystallographic Program System for Minicomputers; Universität Erlangen--Nürnberg, 1977. sity) $322,320\left(6,18, \mathrm{M}^{+}\right), 167(100)$. Anal. Calcd for $\mathrm{C}_{22} \mathrm{H}_{21} \mathrm{Cl}$ : $\mathrm{C}$, $82.35 ; \mathrm{H}, 6.60$. Found: C, $82.47 ; \mathrm{H}, 6.64$

The analogous reaction of $\mathbf{1}^{\prime}$ with $\mathbf{c}-2 \mathrm{~b}$ gave a 1:3 mixture of $\mathbf{c}$ - and $\mathbf{t}-\mathbf{3 b}$ ' which was fractionally crystallized with ethanol to isolate the minor isomer. l-1-Chloro-2-methyl-1,3,3-triphenylpropane (c-3b'): $\mathrm{mp}$ $117-118{ }^{\circ} \mathrm{C}$; ${ }^{1} \mathrm{H}$ NMR see Table III; ${ }^{13} \mathrm{C}$ NMR $\left(\mathrm{CDCl}_{3}\right) \delta 13.14$ (q), 44.53 (d), 54.97 (d), 65.16 (d), 126.35 (d), 127.98 (d), 128.38 (d), 128.86 (d), $137.93(\mathrm{~s}), 142.70(\mathrm{~s}), 142.91(\mathrm{~s})$

Treatment of either c- or $\mathbf{t}-3 \mathbf{b}^{\prime}$ with 0.5 equiv of $\mathrm{TiCl}_{4}$ in $\mathrm{CH}_{2} \mathrm{Cl}_{2}$ at $78^{\circ} \mathrm{C}(45 \mathrm{~min})$ gave $t-2-$ methyl- $r-1, c-3$-diphenylindane $\left(4 \mathrm{~b}^{\prime}\right)$ in quantitative yield: $\mathrm{mp} 92-93^{\circ} \mathrm{C}$ [lit. $\left.{ }^{9 \mathrm{~b}} \mathrm{mp} 91-92{ }^{\circ} \mathrm{C}\right] ;{ }^{13} \mathrm{C} \mathrm{NMR}\left(\mathrm{CDCl}_{3}\right)$ $\delta 15.41$ (q), 56.67 (d), 58.39 (d, double int.), 124.34 (d), 126.53 (d), 126.71 (d), 128.35 (d), 128.71 (d), 143.06 (s), 146.67 (s).

3. Bis(4-methylphenyl)methyl Chloride $\left(1^{\prime \prime}\right)$ and 2-Butenes $\mathrm{c}, \mathrm{t}-2 \mathrm{a}$. A solution of $\mathrm{ZnCl}_{2}(834 \mathrm{mg})$ in $1.0 \mathrm{~mL}$ of diethyl ether and $2.0 \mathrm{~mL}$ of $\mathrm{CH}_{2} \mathrm{Cl}_{2}$ was added to a precooled $\left(-78^{\circ} \mathrm{C}\right)$ solution of $\mathbf{1}^{\prime \prime}(3.40 \mathrm{~g}, 14.7$ $\mathrm{mmol})$ and $\mathrm{t}-2 \mathrm{a}(2.30 \mathrm{~g}, 41.0 \mathrm{mmol})$ in $70 \mathrm{~mL}$ of $\mathrm{CH}_{2} \mathrm{Cl}_{2}$. The reaction mixture was poured onto aqueous ammonia after $22 \mathrm{~h}$ and worked up as described above. The crude product (oil) contained $\mathbf{t}-3 \mathbf{a}^{\prime \prime}$ and $\mathbf{6 a}^{\prime \prime}$ in a 20:1 ratio ( ${ }^{1} \mathrm{H}$ NMR). Crystallization from petroleum ether yielded 1-3-chloro-2-methyl-1,1-bis(4-methylphenyl)butane $\left(\mathrm{t}-3 \mathrm{a}^{\prime \prime}\right)(3.60 \mathrm{~g}, 86 \%)$ mp 77-78 ${ }^{\circ} \mathrm{C}$; ${ }^{1} \mathrm{H}$ NMR, see Table III. Anal. Calcd for $\mathrm{C}_{19} \mathrm{H}_{23} \mathrm{Cl}$ : C, 79.56; H, 8.08. Found: C, 79.13; H, 8.06.

The analogous reaction of $\mathbf{1}^{\prime \prime}$ with c-2a yielded $88 \%$ of a $0.12: 1.0: 0.11: 0.16$ mixture of $\mathbf{t}-3 a^{\prime \prime}, \mathbf{c}-3 \mathbf{a}^{\prime \prime}, 6 \mathbf{a}^{\prime \prime}$, and $7 \mathbf{a}^{\prime \prime}$ (analyzed by ${ }^{1} \mathrm{H}$ NMR).

4. Bis(4-methylphenyl)methyl Chloride $\left(1^{\prime \prime}\right)$ and 1-Phenylpropenes t,c-2b. Compounds t-2b $(1.21 \mathrm{~g}, 10.2 \mathrm{mmol})$ and $\mathbf{1}^{\prime \prime}(2.01 \mathrm{~g}, 8.71 \mathrm{mmol})$ reacted in the presence of $\mathrm{ZnCl}_{2}(0.28 \mathrm{~g})$ and ether $(0.33 \mathrm{~mL})$ in $80 \mathrm{~mL}$ of $\mathrm{CH}_{2} \mathrm{Cl}_{2}$ at $-78{ }^{\circ} \mathrm{C}$ within $3 \mathrm{~h}$ to give $u$-1-chloro-2-methyl-3,3-bis(4methylphenyl)-1-phenylpropane $\left(\mathrm{t}-3 \mathrm{~b}^{\prime \prime}\right)(2.70 \mathrm{~g}, 89 \%)$ as needles: $\mathrm{mp}$ $84-85^{\circ} \mathrm{C}$ (ethanol); ${ }^{1} \mathrm{H}$ NMR, see Table III. Anal. Calcd for $\mathrm{C}_{24} \mathrm{H}_{25} \mathrm{Cl}$ : $\mathrm{C}, 82.62 ; \mathrm{H}, 7.22$. Found: $\mathrm{C}, 82.33 ; \mathrm{H}, 7.20$.

The analogous reaction of $\mathbf{l}^{\prime \prime}$ with $\mathbf{c - 2} \mathbf{b}$ gave a viscous oil $\left(\mathbf{t}-\mathbf{3 b} \mathbf{b}^{\prime \prime} \mathbf{c}-\mathbf{3 b}\right.$ " $=2 ; 1)$ with bp $175-180^{\circ} \mathrm{C}$ (bath) $/ 1.3 \times 10^{-3}$ mbar $(1.10 \mathrm{~g}, 73 \%)$.

II. Determination of the Stereoselectivity. Diphenylmethyl Chloride $\left(1^{\prime}\right)$ and $(E),(Z)$-2-Butenes t,c-2a. Compounds $1^{\prime}(0.5 \pm 0.05 \mathrm{mmol})$ and $\mathrm{t}-2 \mathrm{a}$ or c-2a $(3.5-8.5 \mathrm{mmol}$; purity $>99.6 \%$ by $\mathrm{GC})$ were dissolved in $50 \mathrm{~mL}$ of absolute $\mathrm{CH}_{2} \mathrm{Cl}_{2}$ at $-78^{\circ} \mathrm{C}$. The Lewis acid $(1.0-2.0 \mathrm{mmol})$ was added and stored at $-78^{\circ} \mathrm{C}$ for $14-22 \mathrm{~h}$. The solution was poured on aqueous ammonia, washed with water, dried with $\mathrm{CaCl}_{2}$ and analyzed by HPLC. Conditions: silica gel nucleosil 50-5 (Macherey \& Nagel), isooctane, $1.40 \mathrm{~mL} / \mathrm{min} ; 5 \mathbf{a}^{\prime}(9.60 \mathrm{~min}), 7 \mathbf{a}^{\prime}(10.70 \mathrm{~min}), \mathbf{c}-3 \mathbf{a}^{\prime}(11.20$ $\mathrm{min}), \mathbf{t}-3 \mathbf{a}^{\prime}(11.80 \mathrm{~min})$, or nucleosil $5 \mathrm{C}_{18}$, acetonitrile: $\mathrm{H}_{2} \mathrm{O}: \mathrm{THF}=$ $38: 38: 24,1.40 \mathrm{~mL} / \mathrm{min} ; \mathbf{7 a}^{\prime}(12.59 \mathrm{~min}), \mathbf{t}-3 \mathbf{a}^{\prime}(12.75 \mathrm{~min}), \mathbf{c}-3 \mathbf{a}^{\prime}(13.31$ $\min ), 5 a^{\prime}(13.79 \mathrm{~min}), 6 a^{\prime}(16.59 \mathrm{~min})$. Since $c$ - and $t-3 a^{\prime}$ were not basis line separated on silica gel, and $\mathbf{t}-3 \mathbf{a}^{\prime}$ and $7 \mathbf{a}^{\prime}$ were not basis line separated on the $\mathrm{C}_{18}$ material, each run was analyzed with both separation conditions.

Diarylmethyl Chlorides $1^{\prime}$ and $1^{\prime \prime}$ and $(E),(Z)$-1-Phenylpropenes t,c2b. Solutions of $\mathbf{1}^{\prime}(0.48-0.62 \mathrm{mmol})$ and $\mathbf{t}-2 \mathrm{~b}(100 \%$ by GC, $0.67-0.73$ $\mathrm{mmol})$ or $\mathbf{c - 2 b}(97.6 \%$ by GC, $0.66-0.72 \mathrm{mmol})$ in $50 \mathrm{~mL}$ of absolute $\mathrm{CH}_{2} \mathrm{Cl}_{2}$ were cooled at $-78{ }^{\circ} \mathrm{C}$. Lewis acids $(0.25-2.0 \mathrm{mmol})$ were added, and samples, which were drawn at different times (before and after completion of the reaction), were analyzed by GC (Apiezon $L, 100$ $\left.{ }^{\circ} \mathrm{C} ; \mathbf{c}-2 \mathbf{b}, 2.76 \mathrm{~min} ; \mathbf{t}-2 \mathbf{b}, 3.70 \mathrm{~min}\right)$ and HPLC. Conditions: Nucleosil $7 \mathrm{OH}$ (diol) $($ Macherey \& Nagel), isooctane: tert-butyl methyl ether $=$ $125: 1,1.40 \mathrm{~mL} / \mathrm{min}: 4 \mathbf{b}^{\prime}$ (3.25 $\left.\mathrm{min}\right), \mathbf{c}-3 \mathbf{b}^{\prime}$ (4.27 $\mathrm{min}$ ), $\mathbf{t}-3 \mathbf{b}^{\prime}$ (4.50 $\mathrm{min}$ ). Analogous experiments (without GC analysis) have been carried out in mixtures of $\mathrm{CH}_{2} \mathrm{Cl}_{2}$ and petroleum ether (Table IV).

The reaction of $\mathbf{1}^{\prime \prime}(0.44 \mathrm{mmol})$ with $\mathbf{t}-2 \mathbf{b}(0.70 \mathrm{mmol})$ and $\mathbf{c - 2 b}(0.73$ $\mathrm{mmol})$ in $\mathrm{CH}_{2} \mathrm{Cl}_{2}(50 \mathrm{~mL})$ was catalyzed by $\mathrm{ZnCl}_{2}(1.9 \mathrm{mmol})$. The products were analyzed by HPLC. Conditions: Nucleosil $5 \mathrm{NO}_{2}$ (Macherey \& Nagel), isooctane:diethyl ether $=99: 1,1.35 \mathrm{~mL} / \mathrm{min}) ; \mathbf{c}-3 \mathbf{b}^{\prime \prime}$ $(5.3 \mathrm{~min}), \mathbf{t}-3 \mathbf{b}^{\prime \prime}(5.8 \mathrm{~min})$

Acknowledgment. We thank the Deutsche Forschungsgemeinschaft and the Fonds der Chemischen Industrie for financial support.

Registry No. $\mathbf{1}^{\prime}, 90-99-3 ; \mathbf{1}^{\prime \prime}, 13389-70-3 ; \mathbf{t}-2 \mathrm{a}, 624-64-6 ; \mathbf{c}-2 \mathrm{a}, 590-$ 18-1; t-2b, 873-66-5; c-2b, 766-90-5; t-3a', 102434-92-4; c-3a', 10243493-5; t-3a", 102434-94-6; c-3a", 102434-95-7; t-3b', 102436-14-6; c-3b', 102436-13-5; t-3b", 102436-18-0; c-3b", 102436-17-9; $\mathrm{ZnCl}_{2}, 7646-85-7$; $\mathrm{BCl}_{3}, 10294-34-5 ; \mathrm{SnCl}_{4}, 7646-78-8 ; \mathrm{TiCl}_{4}, 7550-45-0$.

Supplementary Material Available: Atomic coordinates, thermal parameters, interatomic distances and angles (2 pages). Ordering information is given on any current masthead page. 